\section{OSAKKEIDEN LOPULLINEN ARVONMENETYS TULOVEROTUKSESSA}

\section{FINAL LOSS OF VALUE OF SHARES IN INCOME TAXATION}

\section{Ville Rautapää}

DOI: https://doi.org/10.33344/vol13iss2pp76-93

Helsinki Law Review, 2/2019, pp. 76-93

(c) 2019 Pykälä ry, Mannerheimintie 3 B, 5th floor, 00100 Helsinki, Finland, and the author.

\section{$\mathbf{D}$}

Avainsanat:

Tuloverotus, arvonmenetys, arvoton osake, KHO 2016:49

\section{Keywords:}

Income taxation, loss of value, worthless share, $\mathrm{KHO} 2016: 49$

\section{ABSTRACT}

According to the Finnish Income Tax Law (1535/1992, with amendments) Section 50, Subsection 3 , Paragraph 2, loss of value of a security that can be considered final due to bankruptcy or any other comparable reason shall be treated as deductible capital loss. This provision can be divided into four requirements: First, this regulation applies only to securities. As the article examines the problem of the worthless shares in taxation, this definition is not closely examined. Secondly, the security has to lose its value. There is not a definition for loss of value in the Finnish Income Tax Law or in the preparatory works for the regulation. However, the value of the definition is in that it binds the application of the provision to economic facts. Third requirement is that the loss of value has to be final. The finality is especially a matter of income spreading in taxation, as it defines the correct tax year for the deduction. The emphasis of previous research and case law has been on this question of finality. Fourthly, there is the question of bankruptcy or any other comparable reason. In accordance to the case law, this requirement binds the application of this provision to insolvency procedures.

1 Ville Rautapää is a fourth-year law student at the University of Helsinki. This article was inspired by his interest in investing.
Mainly, the application of the provision means that the taxpayer can deduct the whole acquisition cost of the security. However, shareholders can also finance their company with subordinated loans. According to the ruling of the Supreme Administrative Court of Finland (KHO 2016:49), subordinated loans are considered as additional investment and as such they can be fully deducted when the shares in the company are considered to lose their value in income taxation. 


\section{JOHDANTO}

\section{I.I Taustaa}

Ahtium Oyj eli entinen Talvivaara Kaivososakeyhtiö Oyj asetettiin konkurssiin maaliskuussa 2018. Uutisen myötä yhtiön arviolta 80000 omistajan osakkeet menettivät lopullisesti arvonsa. ${ }^{2}$ Verotuksen kannalta merkittävää tässä suhteessa on joulukuussa 2018 Ahtium Oyj:n konkurssipesän hoitajan antama ilmoitus, että yhtiön osakkeenomistajille ei ollut odotettavissa jako-osuutta, jolloin sijoittajat pystyivät viimein vähentämään omistamiensa arvottomien osakkeiden hankintamenot verotuksessaan. ${ }^{3}$ Osakkeiden lopullisesta arvonmenetyksestä säädetäänkin tuloverolain (1535/1992, "TVL") 50.3 §:n 2 kohdassa, jonka mukaan luovutustappioon rinnastetaan sellainen arvopaperin arvonmenetys, jota voidaan konkurssin tai muun siihen verrattavan syyn vuoksi pitää lopullisena. Sanamuotonsa mukaisesti säännöstä voidaan soveltaa kaikkiin arvopapereihin. Korkeimman hallinto-oikeuden (KHO) oikeuskäytännön mukaan esimerkiksi juoksevan velkakirjan lopullinen arvonmenetys on voitu vähentää luovutustappiona. ${ }^{4}$ TVL 50.3 §:n 2 kohta on nimenomaisesti poikkeussäännös tuloverotuksessa, sillä pääsääntöisesti luovutustappion vähentäminen edellyttää omaisuuden luovutusta TVL 50.1 §:n nojalla, eivätkä muiden kuin arvopaperien arvonmenetykset voi pääsääntöisesti tulla vähennettäviksi TVL:n mukaisessa verotuksessa. ${ }^{5}$

Luovutustappiota koskevan TVL 50.1 §:n sanamuodon mukaisesti luovutustappioiden vähentäminen muista tuloista kuin luovutusvoitoista koskee ainoastaan luonnollisia henkilöitä ja kotimaisia kuolinpesiä. Näin ollen esimerkiksi asunto-osakeyhtiön verotuksessa luovutustappiot voidaan vähentää TVL 50.1 §:n nojalla vain luovutusvoitoista asianomaisena verovuonna ja viitenä sitä seuraavana vuotena. ${ }^{6}$ Käytännössä TVL 50.3 §:n 2 kohdan mukaisesta

2 Kauppalehden artikkeli: Ahtiumin konkurssi on sijoittajalle pieni helpotus: "Tuloslaskelmat koomista luettavaa", 7.3.2018. Saatavissa https://www.kauppalehtifi/uutiset/ahtiumin-konkurssi-on-sijoittajallepieni-helpotus-tuloslaskelmat-koomista-luettavaa/b9b037fa-f34f-3c2d-96e5-797f7c56584d haettu 22112019 Huomioitavaa on että entisen Talvivara Kaivosyhtiö Oyjn operativista toiminta hajoittanut tytäryhtiö ty áry Oyj.n Osakkeila keyker. tilikaudelta, s. 2. Saatavissa http://hugin.info/136227/R/2172308/837322.pdf, haettu 22.11.2019.

3 Verohallinnon ohje: Ahtium Oyj:n osakkeiden sekä joukkovelkakirjalainojen arvonmenetys tuloverolain mukaisessa verotuksessa, 11.12.2018, dnro VH/2514/00.01.00/2018, luku 2

$4 \mathrm{KHO} 2018: 11$

5 Räbinä, Timo - Myllymäki, Janne - Myrsky, Matti. Henkilökohtaisen tulon verotus. Helsinki, Alma Talent 2019. (Räbinä - Myllymäki - Myrsky 2019), s. 345. Poikkeuksellisesti menetykset voivat tulla vähennettäväksi myös tulonhankkimismenoina. Ks. KHO 2014:21. Vrt. KHO 2019:6.

6 Asunto-osakeyhtiöiden verotuksesta tarkemmin ks. Tikka, Kari S. - Nykänen, Olli - Juusela, Janne Viitala, Tomi. Yritysverotus I-II. Helsinki, Alma Talent Oy. Jatkuvatäydenteinen teos. Viimeisin päivitys 21.8.2019 haettu 2211.2019. (Tikka ym. 2019) 6. Elinkeinoverolain soveltamisala > Elinkeinonharjoittaja arvopaperin arvonmenetyksestä seuraa, että kyseisen arvopaperin hankintameno vähennetään verovelvollisen tuloverotuksessa ensisijaisesti TVL 50.1 §:n mukaan tämän luovutusvoitoista asianomaisena verovuonna ja viitenä sitä seuraavana vuotena sitä mukaa kuin voittoa kertyy Jos luonnollisen henkilön tai kotimaisen kuolinpesän verotuksessa vähennyskelpoinen luovutustappio jää vähentämättä omaisuuden luovutuksesta saadusta voitosta, vähennetään se puhtaasta pääomatulosta ennen muita pääomatuloista tehtäviä vähennyksiä.

Osakkeiden ja erityisesti pörssiyhtiöiden osakkeiden arvonmenetystä voitaneen pitää yhteiskunnallisesti merkittävimpänä TVL 50.3 §:n 2 kohdan soveltamisen kohteena, sillä niihin voi sisältyä huomattavia yksityishenkilöiden rahallisia panostuksia sijoitusten muodossa, mistä Ahtium Oyj:n tapaus on yksi esimerkki. Erityisesti pörssiyritysten konkursseihin liittyvien arvonmenetysten lopullinen ajankohta voi aiheuttaa oikeudellista epävarmuutta yksityissijoittajille. Tämän oikeudellisen epävarmuuden torjumiseksi Verohallinto onkin antanut ohjeita pörssiyritysten, kuten Elcoteq SE: $n^{\mathbf{7}}$, Ahtium Oyj: $\mathrm{n}^{\mathbf{8}}$ ja Tiimari Oyj: ${ }^{\mathbf{9}}$, osakkeiden arvonmenetyksistä. Näistä syistä tämä artikkeli onkin rajattu käsittelemään nimenomaisest osakkeiden arvonmenetystä, eikä muiden arvopaperien menetyksiä tarkastella.

TVL 50.3 §:n 2 kohdassa tarkoitettu arvopaperin arvonmenetys on myös oikeudellisesti erotettava elinkeinotulon verottamisesta annetussa laissa (360/1968, "EVL") tarkoitetuista arvonalentumisista. Arvonalentumista voitaneen pitää laajempana määritelmänä, joka pitää sisällään myös arvonmenetyksen määritelmän. ${ }^{10}$ Lopullisella arvonmenetyksellä voidaan sanamuodon nojalla katsoa tarkoitettavan sitä, että omaisuuden arvo on kokonaisuudessaan pysyvästi alentunut eli omaisuudesta on tullut arvotonta. "1 Yritysverotusta koskevat pääsääntöisesti omat säännöksensä, joita ei ole tarkoituksenmukaista tarkastella tässä artikkelissa.

7 Verohallinnon ohje: Elcoteq SE:n osakkeiden sekä debentuuri- ja hybridilainojen arvonmenetys tuloverolain mukaisessa verotuksessa, 22.11.2016, dnro A173/200/2016.

8 Verohallinnon ohje: Ahtium Oyj:n osakkeiden sekä joukkovelkakirjalainojen arvonmenetys tuloverolain mukaisessa verotuksessa, 11.12.2018, dnro VH/2514/00.01.0O/2018. Ohjeella on korvattu Verohallinnon ohje: Talvivaaran Kaivososakeyhtiö Oyj:n osakkeiden arvonmenetys, 11.11.2016, dnro A140/200/2016.

9 Verohallinnon ohje: Tiimari Oyj:n osakkeiden arvonmenetys tuloverolain mukaisessa verotuksessa, 5.9.2014, dnro A114/200/2014

10 EVL 17 \&:n 2 kohdan sanamuodon mukaan vähennyskelpoisia ovat rahoitusomaisuuden lopullisiks todetut arvonalenemiset. Vähennyskelpoisuuden edellytyksenä ei ole omaisuuden menetys, vaan muukin pysyväisluontoinen arvonalentuminen voi olla vähennyskelpoinen. Andersson, Edward - Penttilä, Seppo. Elinkeinoverolain kommentaari. Helsinki, Talentum 2014. (Andersson - Penttilä 2014), s. 440. Ks. myös KHO 14.9.1982 taltio 4092, jossa saatava katsottiin lopullisesti arvottomaksi todetuksi, kun yhtiön Irakin valtiota vastaan käymä välimiesmenettely oli pitkittynyt ja tilintarkastaja oli todennut olevan todennäköistä, että Irakin valtiolta ei saada korvausta sen esitettyä vastasaatavavaatimuksen.

11 Ks. myös Kielitoimiston sanakirja, https://www.kielitoimistonsanakirja.fi/arvoton: "Arvoton (tavara)näyte näyte jolla ei ole rahallista arvoa. ." Haettu 22.11.2019. 


\subsection{Tutkimuskysymys ja metodi}

Artikkelin tutkimusongelmana on, milloin kyseeseen voi tulla tuloverotuksessa vähennyskelpoinen arvonmenetys. TVL 50.3 §:n 2 kohdan säännöksen sanamuodosta on havaittavissa, että sen soveltamista on tarkasteltava neljän edellytyksen kautta. Ensinnäkin kyseessä tulee olla arvopaperi. Tässä artikkelissa on tarkoitus käsitellä vain osakkeiden arvonmenetyksiä, joten tätä määritelmää ei tarkastella sen tarkemmin. Toiseksi kyseessä tulee olla arvonmenetys. Kolmanneksi arvonmenetyksen tulee olla sellainen, jota voidaan pitää lopullisena, ja neljänneksi sen tulee olla lopullinen konkurssin tai siihen verrattavan syyn vuoksi. Käytännön näkökulmasta on myös tärkeää tietää, kuinka suuri vähennyske/poinen arvonmenetys on. Tutkimusongelma voidaan täten jakaa osakysymyksiin, joiden avulla osakkeiden lopullista arvonmenetystä verotuksessa voidaan tarkastella:

\section{- Mitä arvonmenetys tarkoittaa? (Luku 2)}

- Milloin arvonmenetys on lopullinen? (Luku 3)

- Mitkä konkurssiin verrattavat syyt aktualisoivat säännöksen soveltamisen? (Luku 3)

- Kuinka suuren arvonmenetyksen voi verotuksessa vähentää? (Luku 4)

Artikkeli on lainopillinen tutkimus, koska osakkeiden lopullisen arvonmenetyksen sisällön selvittämisessä on pohjimmiltaan kysymys yhden säännöksen tulkinnasta. Tulkinnan kannalta on haasteellista, että TVL 50.3 §:n 2 kohdan määritelmää arvonmenetykselle voidaan pitää hyvin väljänä eikä TVL:ssa tai lain esitöissä ole tarkempaa määritelmää arvonmenetykselle. ${ }^{\mathbf{1 2}}$ Osakkeen taustalla olevan yhtiön arvostukseen ei voida myöskään soveltaa arvostamislakia. ${ }^{13}$ Siten säännöksen sisällön selvittäminen edellyttää nimenomaisesti lainopillista tutkimusta. Näkemykseni mukaan osakkeiden arvonmenetyksestä tarvitaankin lisää oikeustieteellistä keskustelua.

Eri viranomaisten, kuten KHO:n, keskusverolautakunnan (KVL) ja hallinto-oikeuksien (HAO) oikeuskäytännöstä on havaittavissa suuntaviivoja ja oikeusohjeita TVL 50.3 §:n 2 kohdan

12 Hallituksen esityksessä todetaan melko lakonisesti, että "[t]appioon rinnastettaisiin vastaisuudessa myös sellainen omaisuuden arvonmenetys, jota voidaan pitää lopullisena. Näitä tilanteita ovat ainakin konkurssi ja option raukeaminen." Ks. HE 200/1992 vp - Hallituksen esitys Eduskunnalle tuloverolaiksi sekä laiksi eräiden yleishyödyllisten yhteisöjen verohuojennuksista annetun lain 1 ja 6 \&:n muuttamisesta, s.39.

Varojen arvostamisesta verotuksessa annetun lain (22.12.2005/1142) soveltamisalaa koskevan 1 §:n mukaan tuloverolaissa (1535/1992) tarkoitetun jaettavan yritystulon ja yhtymän osakkaan tulo-osuuden pääomatulo-osuuden perusteena oleva nettovarallisuus sekä osakkeen matemaattinen arvo samoin kuin kiinteistöveron perusteena olevan kiinteistön arvo lasketaan siten kuin tässä laissa säädetään. Ks. myös Verohallinnon ohje: Varojen arvostaminen perintö- ja lahjaverotuksessa, 25.9.2018, dnro A121/200/2018, luku 1.1 . soveltamiseen. Arvonmenetystä on myös käsitelty Verohallinnon yleisissä ohjeissa ${ }^{\mathbf{1 4}}$, mutta nämä viranomaisohjeistukset ovat osittain kollisiossa oikeuskäytännössä esitettyjen lähtökohtien kanssa, kuten jäljemmin esitetään. Näistä näkökulmista säännöksen sanamuodon ja oikeuskäytännön asemaa oikeuslähteinä voidaan pitää korostuneena.

\section{ARVONMENETYS}

\section{I Oikeuskäytäntö}

Johdannossa esitetyllä tavalla TVL 50.3 §:n 2 kohdan soveltamiselle voidaan esittää neljä edellytystä. Arvopaperin käsite on rajattu pois, joten seuraavaksi edellytykseksi nousee arvonmenetys. Määritelmää arvonmenetykselle ei kuitenkaan löydy laista tai sen esitöistä, eikä asiaa ole juuri käsitelty kotimaisessa oikeuskirjallisuudessakaan.

Myös oikeuskäytännössä huomio on harvoin kohdistunut arvonmenetykseen. Poikkeuksen muodostaa ratkaisu Vaasan HAO 13.3.2009 taltio 09/0104/3 (lainvoimainen), jossa aviopuolisot olivat ostaneet Thaimaasta lomaosakkeen, jonka vastikkeeksi he olivat antaneet lomaosakkeensa Espanjassa sekä rahaa. Thaimaan lomaosaketta ei ollut luovutettu puolisoille, ja heidän vastapuolensa oli tuomittu asiasta seuranneessa rikosoikeudenkäynnissä rangaistukseen törkeästä petoksesta ja velvoitettu suorittamaan aviopuolisoille vahingonkorvausta. Aviopuolisot olivat vaatineet Espanjan lomaosakkeen menetyksen vahvistamista luovutustappiona TVL 50.3 §:n 3 kohdan (nyk. 2 kohdan) nojalla. Verotuksen oikaisulautakunta oli hyväksynyt heidän vaatimuksensa. Hallinto-oikeus kuitenkin katsoi, että säännös soveltuu tilanteisiin, joissa arvopaperin markkina-arvo on pysyvästi alentunut. Tapauksessa esitetty tahallinen erehdytys ei tarkoittanut, että lomaosakkeen arvo olisi muuttunut. Hallinto-oikeus katsoi myös, että rikosta ei voitu pitää konkurssiin rinnastettavana tapahtumana.

Hallinto-oikeus siis arvioi osakkeen arvoon kohdistuvaa muutosta itsenäisenä edellytyksenä. Arvonmuutosta ei ollut tapahtunut, sillä kyse oli vain asianosaisten omaan varallisuusasemaan kohdistuneesta muutoksesta, joka oli johtunut tahallisesta erehdyttämisestä. Osakkeen arvon ei näin ollen lähtökohtaisesti voitane katsoa muuttuvan pelkän omistaja-aseman muutoksesta.

Ratkaisussa KHO 1991 B 540 15 oli kyse holdingyhtiön omistamien osakkeiden muuttumisesta arvottomiksi. X Oy oli hankkinut 15.10.1984 Y Oy:n osakkeita. Y Oy oli asetettu 1986 konkurssiin,

14 Verohallinnon ohje: Omaisuuden luovutusvoitot ja -tappiot luonnollisen henkilön tuloverotuksessa, 31.10.2019, dnro VH/330/00.01.00/2019, luku 13.2 ja Verohallinnon ohje: Arvopaperien luovutusten verotus, 4.10.2019, dnro VH/2358/00.01.00/2019, luku 23.2.

15 Ratkaisu on annettu nykyisen TVL:n säätämistä edeltävältä ajalta, jolloin arvonmenetystä ei ollut säädetty lainkaan vähennyskelpoiseksi. 
joka oli rauennut varojen puuttuessa. Y Oy oli merkitty kaupparekisteriin lakanneeksi 31.12.1986. $X$ Oy ei ollut saanut $Y$ Oy:stä jako-osuutta. Y Oy:n osakkeiden arvonmenetystä ei ollut hyväksytty $X$ Oy:n verotuksessa vähennyskelpoiseksi.

Lääninoikeudessa X Oy oli vaatinut $Y$ Oy:n osakkeiden arvottomaksi käymisestä aiheutuneen tappion vähentämistä yhtiön verotuksessa, koska tappio oli syntynyt yhtiön tavanomaisessa sijoitustoiminnassa. Lääninoikeus oli hyväksynyt $X$ Oy:n vaatimuksen ja kumonnut toimitetun verotuksen. Tarkastusasiamiehen valituksen myötä KHO kumosi lääninoikeuden päätöksen ja saattoi verolautakunnan toimittaman verotuksen voimaan. KHO:n perustelut kohdistuvat lähinnä siihen, että Y Oy:n osakkeiden arvonmenetystä ei voitu pitää luovutuksena eikä menetyksiä muutoin ollut säädetty vähennyskelpoisiksi tuolloin.

Ratkaisussa arvonmenetyksen määrittelyyn ei suoranaisesti otettu kantaa, koska tilannetta pidettiin selvänä. X Oy ei ollut saanut $Y$ Oy:stä jako-osuutta ja Y Oy oli purkautunut. ${ }^{16}$ Tapausta voitaneen pitää osakkeiden arvonmenetyksen tyyppitilanteena; osakkeenomistaja ei ole saanut yrityksestä konkurssin myötä lainkaan jako-osuutta, eikä yritys voi enää toimia purkauduttuaan.

\subsection{Arvonmenetyksen käsite ja varojen arvostaminen}

Edellä mainituista ratkaisuista on vaikeaa tehdä yhteenvetoa siitä, milloin osakkeen arvo on menetetty TVL 50.3 §:n 2 kohdassa tarkoitetulla tavalla. Hallinto-oikeuden maininta lomaosakkeen markkina-arvon muuttumattomuudesta ratkaisussa Vaasan HAO13.3.2009 taltio 09/0104/3 johdattaa kuitenkin kysymykseen arvonmenetyksen määrittelystä, jolloin käsitteellä olisi säännöksessä myös itsenäistä merkitystä. Nähdäkseni lainsäätäjän tarkoituksena ei vaikuta olleen määritellä arvonmenetystä taloudellisista faktoista poikkeavalla tavalla, sillä muuten määritelmää olisi käsitelty erikseen joko lain esitöissä tai itse laissa.

Osakkeen arvonmenetyksen käsitteessä on kyse siitä, että osakkeen arvo on nolla. ${ }^{17}$ Vaikka käsite vaikuttaa teoriassa hyvin yksinkertaiselta, käytännössä voi olla vaikeaa määritellä, milloin yritystä on pidettävä arvottomana. Yleisesti osakkeen taustalla olevan yrityksen arvon määrittelyä on tarkasteltu liiketaloustieteessä, jossa arvonmäärityksen lähtökohtana ovat

16 Tällaisessa tapauksessa on selvää, että yrityksen markkina-arvo on nolla, sillä yrityksestä ei ole tullut osakkeenomistajille lainkaan jako-osuutta, eikä tällaiselle konkurssiyritykselle ole tarjolla ulkopuolisia ostajia. Lisäksi todettakoon, että purkautuminen katsotaan erikseen arvonmenetyksen lopullisuuden vahvistavaksi tekijäksi. Ks. myös KVL 1996/111.

17 Ks. Seppänen, Harri. Yrityksen arvonmääritys. Helsinki, Alma Talent Oy 2017. (Seppänen 2017), s.161.

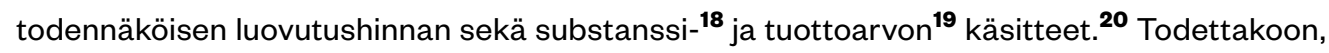
että nämä lähtökohdat on myös hyväksytty noteeraamattoman osakkeen arvostamisessa perintö- ja lahjaverotuksessa. ${ }^{21}$ Verohallinnon ohjeessa ei ole kuitenkaan erikseen todettu, milloin osake voidaan tällaisessa arvonmäärittelyssä todeta arvottomaksi. Noteerattujen osakkeiden osalta kysymys arvonmäärittelystä ei ole yhtä mielekäs, sillä niiden markkina-arvo määrittyy julkisella markkinapaikalla, kuten pörssissä. ${ }^{\mathbf{2 2}}$

Yhtiön substanssiarvon toteaminen lienee useimmiten yksinkertaista, vaikkakin tiettyjen varallisuuserien arvostaminen itsessään voi tuottaa haasteita. ${ }^{\mathbf{2 3}}$ Sen sijaan tuottoarvon määritteleminen on huomattavasti ongelmallisempaa, sillä se edellyttää tulevaisuuden arviointia nykyisyyteen pohjautuvin luvuin. ${ }^{24}$

On huomautettava, että arvonmenetyksen käsitteen aineellisoikeudelliset kysymykset tulee erottaa prosessuaalisista seikoista. Luonnollisesti osakkeen lopullisen arvonmenetyksen soveltumisen edellytyksenä on, että osake on arvoton eli sen markkina-arvo on nolla. Eri asia on kuitenkin tämän osakkeen arvottomuuden osoittaminen todeksi eli näyttökysymyksistä. Jälkimmäistä kysymystä lieventää kuitenkin jäljempänä tarkasteltava lopullisuuden vaatimus, eivätkä arvostamisongelmat tule itsessään useimmiten kyseeseen. ${ }^{25}$ Näin arvonmäärityksen soveltuminen osakkeiden lopullisessa arvonmenetyksessä on kyseenalaista, sillä tyyppi-

18 Substanssiarvolla tarkoitetaan yleisesti varojen ja velkojen erotusta. Penttilä, Seppo: Osakkeen arvo verotuksessa. Jyväskylä, Finnubublishers 1991. (Penttilä 1991), s. 231 ja Pönkä, Ville: Osakkeen lunastaminen: Osakeyhtiö-ja sopimusoikeudellinen tutkimus. Helsinki, Talentum Oyj 2015. (Pönkä 2015), s. 260-261.

19 Tuottoarvo kohdistuu yrityksen tulevaisuudessa odotettaviin nettotuloihin ja siten yrityksen tulevaisuudennäkymiin. Tuottoarvon laskemiselle on kehitetty liiketaloustieteessä useita malleja, mutta yksimielisyyttä oikeasta laskentatavasta ei ole. Ks. Penttilä 1991, s. 224 ja Pönkä 2015, s. 263.

20 Penttilä 1991, s. 222ja Ossa, Jaakko: Yrityksen arvostaminen - vero-oikeudellinen näkökulma. Teoksessa: Yhteisöoikeudellisia kirjoituksia II, toim. Ari Saarnilehto. Turku, Turun yliopisto, 2002, s. 83-104. (Ossa 2002), s. 84.

21 Verohallinnon ohje: Varojen arvostaminen perintö- ja lahjaverotuksessa, 25.9.2018, dnro A121/200/2018, luku 2.5 ja luku 5.

22 Ks. Kukkonen, Matti: Osakeyhtiön myynnin verotus. Helsinki, Lakimiesliton kustannus 1994, s.232 ja Verohallinnon ohje: Varojen arvostaminen perintö- ja lahjaverotuksessa, 25.9.2018, dnro A121/200/2018, luku 2.4.

23 Esimerkiksi immateriaalioikeuksien arvostaminen taseeseen voi tuottaa myös käytännön ongelmia kirjanpidossa, sillä niiden arvon määrittely pohjautuu subjektiiviseen arvioon, ellei oikeuksia ole myyty. Bergström, Pia: Immateriaalioikeuksien arvostaminen - Osa yrityksen arvonmääritystä. Defensor Legis 3/2002, s. 460-478. (Bergström 2002), s. 467.

24 Ks. Ossa 2002, s. 92 ja Penttilä 1991, s.224.

25 Ks. myös Penttilä 1991, s.486, alaviite 12 . 
tapauksena osakkeiden arvonmenetyksessä voitaneen säännöksen sanamuodon perusteella pitää yrityksen konkurssia ja siinä todettua yrityksen arvottomuutta. Tällöin arvonmenetystä koskeva problematiikka aiheuttanee harvoin arvostamiseen liittyviä teoreettisia tulkintaongelmia, sillä arvonmenetystä voidaan pitää selkeänä. ${ }^{26}$ Selvää kuitenkin on, että arvonmenetys ei voi olla osittainen eli osakkeella ei voi olla edes osittaista markkina-arvoa. ${ }^{27}$

Arvonmenetystä, ja siten arvonmäärittelyä, on loppujen lopuksi käsitelty harvoin itsenäisenä edellytyksenä. Oikeus- ja verotuskäytännössä mielenkiinto on sen sijaan kohdistunut arvonmenetyksen lopullisuuteen ja siten luovutustappioiden oikeaan verovuoteen. ${ }^{\mathbf{2 8}}$

\section{LOPULLISUUS KONKURSSIN TAI SIIHEN VERRATTAVAN SYYN VUOKSI}

TVL 50.3 §:n 2 kohdan kolmantena edellytyksenä on arvonmenetyksen lopullisuus. Lisäksi neljäntenä edellytyksenä on, että arvonmenetystä voidaan pitää lopullisena konkurssin tai muun siihen verrattavan syyn vuoksi. Säännöksen sanamuodossa edellytykset ovat oikeastaan yhdistetty $^{29}$, joten niitä on luontevinta käsitellä myös yhdessä. Toisaalta edellä käsitellyssä ratkaisussa Vaasan HAO 13.3.2009 T 09/0104/3 hallinto-oikeus totesi erikseen, että rikosta ei voida pitää konkurssiin verrattavana syynä. Niinpä konkurssia tai siihen verrattavaa syytä tulee pitää itsenäisenä edellytyksenä.

Lopullisuuden edellytys vaikuttaa osakkeen hankintamenon jaksottamiseen eli siihen, mikä on arvonmenetyksestä syntyneen luovutustappion oikea verovuosi. ${ }^{30}$ Konkurssin osalta jaksottamiseen ja arvonmenetyksen lopullisuuden määrittelyyn vaikuttavat etenkin ratkaisut KVL 111/1996 ja KHO 2011:55.

Keskusverolautakunnan ennakkoratkaisun KVL 111/1996 nojalla konkurssin osalta on katsottava, että arvonmenetys muodostuu lopulliseksi viimeistään silloin, kun toimitsijamiehet antavat

26 Ks. myös Penttilä 1991, s.486, alaviite 12 .

27 Ks. KHO 24.7.1973 taltio 2848 ja Nykänen, Pekka: Menetysten vähennyskelpoisuudesta tuloverolain mukaisessa verotuksessa. Teoksessa: Yritys, omistaja ja verotus - Juhlajulkaisu Seppo Penttilälle, toim. Pekka Nykänen ja Matti Urpilainen. Helsinki, Edita Publishing Oy, 2014, s.291-307. (Nykänen 2014), s.296.

28 Ks. KHO 2011:55 ja KVL 111/1996. Ks. myös Verohallinnon ohje: Elcoteq SE:n osakkeiden sekä debentuurija hybridilainojen arvonmenetys tuloverolain mukaisessa verotuksessa, 22.11.2016, dnro A173/200/2016, luku 1.

29 Säännöksen sanamuodon ilmaisu "voidaan pitää - - syyn vuoksi" linkittää edellytykset yhteen

30 Nykänen, Pekka - Räbinä, Timo: Yksityishenkilöiden luovutusvoittojen verotus. Helsinki, Talentum Oyj 2013. (Nykänen - Räbinä 2013), s. 546-547. lopputilityksensä velkojankokouksessa eikä osakkeenomistajille tule jako-osuutta. ${ }^{31}$ Ratkaisun KHO 2011:55 nojalla arvonmenetystä voidaan pitää lopullisena jo ennen lopputilitystä, jos on selvää, että konkurssipesästä ei jää jako-osuutta osakkeenomistajille. Jako-osuuden saaminen linkittyy vahvasti yrityksen substanssiarvoon. ${ }^{\mathbf{3 2}}$

Ratkaisussa KHO 2011:55 osakeyhtiön oma pääoma oli menetetty tilivuoden 2003 aikana ja yhtiö oli asetettu konkurssiin vuonna 2005. Yhtiön konkurssipesän jakoluettelo oli vahvistettu vuonna 2006 ja lopputilitys annettu vuonna 2007. Asiassa esitetyn selvityksen perusteella KHO katsoi, että jo konkurssiinasettamisvuonna 2005 oli ollut selvää, ettei konkurssipesästä jää jakoosuutta osakkeenomistajille. Näin ollen osakkeiden arvonmenetys oli muodostunut lopulliseksi jo vuonna 2005. Osakkeiden hankintameno oli siis vähennettävissä verovuonna 2005.

Näihin kahteen ratkaisuun on myös viitattu säännönmukaisesti Verohallinnon ohjeissa koskien pörssiosakkeiden arvonmenetystä. Ohjeissa on painotettu etenkin arvonmenetyksen lopullisuuden todentamisen prosessuaalista puolta eli sitä, että konkurssissa arvonmenetys tulisi todentaa lopulliseksi joko lopputilityksen tai pesänhoitajan ilmoituksen nojalla. ${ }^{\mathbf{3 3}}$

Keinotekoiset toimenpiteet luovutustappion saamiseksi voidaan katsoa verotusmenettelystä annetun lain (1558/1995) 28 §:n nojalla veron kiertämiseksi. Esimerkiksi ratkaisussa Itä-Suomen HAO 29.1.2019 19 taltio 19/0071/1 (lainvoimainen) A oli omistanut 3000 kpl X Oyj:n osakkeita. $X$ Oyj oli asetettu konkurssiin 17.7.2014 ja A oli myynyt omistamansa ja käytännössä arvonsa menettäneet X Oyj:n osakkeet nimelliseen yhden euron hintaan puolisolleen. Näin menetellen A:lle oli syntynyt noin 15000 euron suuruinen luovutustappio, eikä A ollut esittänyt verotuksesta riippumattomia syitä toimilleen. Ei ollut myöskään ilmennyt, että osakkeiden arvonmenetys olisi ollut TVL 50.3 §:n 2 kohdassa tarkoitetulla tavalla lopullinen vielä verovuonna 2015. Hallintooikeus katsoi, että kyse oli veron kiertämisestä, eikä A:lla ollut oikeutta vähentää $X$ Oyj:n

31 Ks. myös KVL 72/1986, jossa keskusverolautakunta katsoi yhtiön purkautumistilanteessa osakkeiden luovutusajankohdaksi sen verovuoden, jolloin selvitysmiehet olivat esittäneet yhtiökokoukselle lopputilityksen

32 Yhtiön varallisuus ylittää yhtiön velat, jos osakkeenomistajat saavat jako-osuuden osakkeilleen konkurssin päätyttyä. Osakeyhtiölain (624/2006) 20:15:n nojalla yhtiön omaisuus voidaan jakaa vasta, kun kaikki tiedossa olevat velat on maksettu.

33 Verohallinnon ohje: Tiimari Oyj:n osakkeiden arvonmenetys tuloverolain mukaisessa verotuksessa, 5.9.2014, dnro A114/200/2014: "Tiimari Oyj:n osakkeiden perusteella aiheutuva arvonmenetys on lopullinen tuloverolain mukaisessa verotuksessa kun: konkurssipesänhoitaja antaa ilmoituksen, ettei jakoosuutta kerry, tai konkurssipesän lopputilitys tehdään". Ks. myös aikaisempi Verohallinnon ohje: Elooteq SE:n osakkeiden arvonmenetys tuloverolain mukaisessa verotuksessa, 23.4.2012, dnro A17/200/2012 ja Verohallinnon ohje: Arvopaperien luovutusten verotus, 410.2019, dnro VH/2358/00.01.00/2018, ja Verohal"Kon luku 23.2: Kon tuloverolain mukaisessa verotuksessa kun: konkurssipesänhoitaja antaa ilmoituksen, ettäjako-osuutt ei kerry; tai, konkurssipesän lopputilitys tehdään." 
hankintamenoa luovutustappiona. ${ }^{\mathbf{3 4}}$ Tapauksessa oli itse asiassa yritetty kiertää TVL 50.3 §:n menetyksiä koskevia säännöksiä yrittämällä käyttää hyväkseen TVL 50.1 §:n säännöksiä luovutustappioiden vähennyskelpoisuudesta.

Ratkaisussa KHO 1976-B-II-513 katsottiin, että holdingyhtiö sai vähentää tuloistaan konserniin kuuluneen yhtiön purkautumisesta johtuneen osakkeiden arvonmenetyksen. ${ }^{35}$ Julkaisemattomassa ratkaisussa KHO 25.10.2016 taltio $4511 \mathrm{KHO}$ katsoi, että ns. realisaatiosaneerauksessa, jossa yhtiön koko omaisuus realisoidaan ja realisaatiokertymä tilitetään yhtiön velkojille, arvonmenetys oli lopullinen jo saneerausmenettelyn aloittamisvuonna. ${ }^{\mathbf{3 6}}$ Yhtiön omaisuus oli lähes kokonaan realisoitu, eikä yhtiöön realisoinnin jälkeen ollut tarkoitus jäädä liiketoimintaa. Pieniä omaisuuseriä oli jätetty yhtiöön kattamaan lakisääteiset vastuut ja takuut yksityisille talopakettiasiakkaille. ${ }^{37}$

Ratkaisuista voidaan päätellä, että osakkeen arvonmenetyksen lopullisuus edellyttää taustalla olevan yrityksen realisointia tavalla tai toisella taikka siihen pyrkivää menettelyä. Arvonmenetyksen lopullisuus ei kuitenkaan näyttäisi edellyttävän, että yritys on purkautunut ja poistettu kaupparekisteristä. ${ }^{38}$

Olennainen kysymys on, kuinka arvonmenetyksen lopullisuus todetaan. Verohallinto on ohjeistuksissaan painottanut erityisesti arvonmenetyksen lopullisuuden prosessuaalista todentamista esimerkiksi pesänhoitajan ilmoituksen avulla. KHO:n oikeuskäytännössä on sen sijaan johdonmukaisesti todettu, että myös taloudelliset tosiasiat voivat osoittaa arvonmenetyksen lopullisuuden. Näissä tapauksissa verovuodeksi on katsottu realisointimenettelyn aloitusvuosi. ${ }^{39}$ Tapauksissa on ollut oleellista arvonmenetyksen lopullisuuden osoittaminen objektiivisin kriteerein.

34 Ks. myös Andersson, Edward - Linnakangas, Esko - Frände, Joakim: Tuloverotus. Helsinki, Alma Talent, 2016 (Andersson - Linnakangas - Frände 2016), s.274-275 ja Räbinä - Myllymäki - Myrsky 2019, s. 342. Edestakaisista arvopaperikaupoista ks. esim. KHO 2004:8 ja KHO 2012:5. Vrt. KHO 2009:53.

35 Tapaukseen sovellettiin EVL.n säännöksiä, mutta analogia TVL.n mukaisiin arvonmenetyksiin on ilmeinen. Toisaalta vapaaehtoista purkautumista pidetään luovutuksena jossa osakas vaihtaa yhtiön ilmeinen. Tolsaalta vapaaehtolsta purkautumista pidetaán luvion osakkeet yhtiöstä saatavaan jako-osuuteen. Ks. Verc verotuksessa, 7.8.2017, dnro A58/200/2017, luku 1.2.

36 Huomionarvoisena voidaan pitää, että veronsaajien oikeudenvalvontayksikkö oli vastineessaan vedonnut nimenomaisesti saneerauksen menettelyllisiin seikkoihin: "Yhtiön saneerausmenettelyn valvojan lausunnoissa 12.12.2012 tai 4.6.2013 ei todeta, että yhtiön osakkeenomistajille ei tule yrityssaneerauksessa jako-osuutta." Ratkaisun nojalla voidaan katsoa, että Verohallinnon ohjeissaan esittämä vaatimus esimerkiksi konkurssipesän selvitysmiehen antamasta todistuksesta on perusteeton ainakin ehdottomana edellytyksenä.

37 Yrityksen substanssiarvo oli siten nolla, sillä varat eivät ylittäneet velkoja ja vastuita.

38 Arg. KHO 25.10.2016 taltio 4511.

39 Ks. Myrsky, Matti - Malmgrén, Marianne: Elinkeinotulon verotus. Helsinki, Talentum, 2014. (Myrsky Malmgrén 2014), s. 206.
Kumpaa tulkintalinjaa on pidettävä pääsääntönä? Sinänsäsäännöksessäitsessäänjo edellytetään konkurssia tai siihen verrattavaa syytä, joten säännöksen soveltamisen edellytyksenä on lähtökohtaisesti jokin insolvenssioikeudellinen menettely. Toisaalta säännöksessä ei edellytetä ehdotonta prosessuaalista lopullisuutta. ${ }^{\mathbf{4 0}}$ Lisäksi arvonmenetyksen lopullisuuden arviointi puhtaasti Verohallinnon painottamassa prosessuaalisessa tulkintatavassa voi etäännyttää verotuksen taloudellisista realiteeteista. ${ }^{41}$ Tässä valossa Verohallinnon tulkintalinjaa voidaan pitää huomattavasti suppeampana kuin KHO:n tuoreessa käytännössä noudatettua linjaa.

\section{ARVONMENETYKSEN SUURUUS}

\section{I Hankintameno}

Arvonmenetys rinnastuu TVL 50.3 §:n 2 kohdan nojalla luovutustappioon, kun osakkeiden arvonmenetys on lopullinen. TVL 50.1 §:n mukaan omaisuuden luovutuksesta syntynyt tappio vähennetään omaisuuden luovutuksesta saadusta voitosta verovuonna ja viitenä sitä seuraavana vuotena sitä mukaa kuin voittoa kertyy. Luonnollisen henkilön ja kotimaisen kuolinpesän verotuksessa vähennyskelpoinen luovutusvoitoista vähentämättä jäänyt luovutustappio vähennetään puhtaasta pääomatulosta ennen muita pääomatuloista tehtäviä vähennyksiä Omaisuuden luovutuksesta syntynyttä tappiota ei oteta huomioon pääomatulojen alijäämää vahvistettaessa. ${ }^{42}$

Olennaista lopullisen arvonmenetyksen aiheuttaman luovutustappion laskemisessa on osakkeiden hankintameno. Esimerkiksi pörssiosakkeiden osalta hankintamenona on pidettävä yksinkertaisesti niiden hankintahintaa. Jos verovelvollinen on esimerkiksi vuonna 2016 ostanut pörssiosakkeita 100000 eurolla, niiden hankintameno on tuolloin 100000 euroa. Jos pörssiosakkeiden arvo on lopullisesti menetetty vuonna 2019, verovelvollinen voi vähentää tuon 100000 euron hankintamenon kokonaisuudessaan vuoden 2019 verotuksessa. Lisäksi, jos tappioita ei voida kokonaisuudessaan vähentää tänä verovuonna, niitä voidaan vähentää myös seuraavina viitenä vuotena sitä mukaa kuin verovelvollinen saa luovutusvoittoa taikka pääomatuloja, jos kyseessä on luonnollinen henkilö tai kotimainen kuolinpesä.

40 Säännöksen sanamuoto "voidaan - - pitää lopullisena" antaa harkintavaltaa. Tilanne olisi luonnollises eri, jos säännöksen sanamuoto olisi on konkurssin tai muun siihen verrattavan syyn vuoksi lopullinen Näin ollen edellytyksenä ei voi olla, että insolvenssimenettely olisi päättynyt, mikä on todennettavissa myös ratkaisusta $\mathrm{KHO} 25.10 .2016$ taltio 4511.

41 Ks. esim. KHO 2014:66 ja KHO 2018:40, joissa KHO on todennut, etta verotuksessa on pyrittävä arvioimaan tehtyjä toimenpiteitä niiden tosiasiallisen luonteen mukaan. Toisaalta mainittu koski veron kiertämistä koskevan verotusmenettelystä annetun lain 28 \&.n soveltamista, eikä osakkeen lopullisessa arvonmenetyksessä ole kyse varsinaisesti verovelvollisen taloudellisista toimenpiteistä

42 Pääomatulojen alijäämästä tarkemmin ks. Andersson - Linnakangas - Frände 2016, s. 215-218. 
Osakkeiden lopullinen arvonmenetys tarkoittaa toisin sanoen käytännössä sitä, että osakkeiden hankintameno saadaan vähentää kokonaisuudessaan verotuksessa. Näin ollen kyse on erityisesti jaksotusongelmasta verotuksessa. ${ }^{43}$ Edellä kuvatun esimerkkitilanteen lisäksi voi tulla vastaan useita erityistilanteita, joissa hankintamenon määrittely ei ole yhtä yksinkertaista. TVL 47.1 §:n nojalla vastikkeettomien saantojen, kuten perinnön ja lahjan, osalta hankintameno on perintö-ja lahjaverotuksessa käytetty verotusarvo. Niinpä myös lahjaksi saatujen osakkeiden lopullinen arvonmenetys on verotuksessa vähennyskelpoinen. ${ }^{44}$

\subsection{Pääomalainat (KHO 2016:49)}

Osakkeiden arvonmenetyksen määrittelemiseen liittyy erityistapauksena pääomalainojen vaikutus hankintamenon laskemiseen. Oikeustilaan tältä osin vaikuttaa merkittävästi korkeimman hallinto-oikeuden ratkaisu KHO 2016:49.

Ratkaisussa yhtiö B Oy oli asetettu konkurssiin vuonna 2010. A oli ollut B Oy:n osakkeenomistaja ja antanut yhtiölle pääomalainaa vuosina 2007 ja 2009. Vuoden 2007 pääomalaina oli annettu, koska yhtiö oli tarvinnut osakkeenomistajiltaan rahoitusta osakekauppaa varten. Tämä laina oli sopimuksen mukaan vakuudeton ja viimesijainen yhtiön konkurssissa. Lainan tai korkojen takaisinmaksu oli lisäksi sovittu sallituksi vain silloin, kun vapaan oman pääoman ja kaikkien pääomalainojen määrä maksuhetkellä oli ylittänyt viimeksi päättyneeltä tilikaudelta vahvistettavan tai sitä uudempaan tilinpäätökseen sisältyvän taseen mukaisen tappion määrän. Toimitetussa verotuksessa vuoden 2009 pääomalaina oli rinnastettu B Oy:n osakkeiden hankintamenoon, kun taas vuoden 2007 pääomalaina katsottiin tavallisen saatavan menetykseksi, jota ei voitu vähentää luovutustappiona. Sekä verotuksen oikaisulautakunta että hallinto-oikeus hylkäsivät A:n valituksen.

Korkein hallinto-oikeus hyväksyi A:n valituksen. Korkeimman hallinto-oikeuden perustelut asiassa ovat lyhyet. Ensinnäkin perusteluissa todetaan, että TVL:ssa ei ole nimenomaista säännöstä siitä, mitkä erät luetaan luonnollisen henkilön verotuksessa tämän hankkimien osakkeiden hankintamenoon. Korkein hallinto-oikeus totesi vakiintuneesti katsotun, että luonnollisen henkilön tuloverotuksessa hänen omistamiensa osakkeiden hankintamenoon luetaan muun muassa hänen osakkeiden hankinnan jälkeen yhtiöön tekemänsä lisäsijoitukset. Näin ollen ratkaisussa arvioitiin tosiasiallisesti sitä, oliko kyseinen vuonna 2007 annettu pääomalaina A:n tekemä lisäsijoitus yhtiöön. Korkein hallinto-oikeus arvioi tehdyn pääomalainasopimuksen

43 Nykänen 2014, s.295-296

4 Ks. Andersson - Linnakangas - Frände 2016, s. 273-274 ja Niskakangas, Heikki - Knuutinen, Reijo. Henkilöverotus. Alma Talent Oy, Jatkuvatäydenteinen teos. Viimeisin päivitys 7.11.2019, viitattu 22.11.2019. (Niskakangas - Knuutinen 2019), 5. Luovutusvoitot > Luovutustappio > Vastikkeeton saanto. ehtojen ${ }^{45}$ nojalla, että pääomalainaa tuli pitää A:n tekemänä lisäsijoituksena, joten se tuli lukea tämän menettämien osakkeiden hankintamenoon, kun $A$ ei ollut saanut velkapääomaa takaisin B Oy:n konkurssissa.

Korkein hallinto-oikeus ei antanut ratkaisussa merkitystä lainan tarkoitukselle, vaan arvioi lähinnä pääomalainan ehtoja. ${ }^{46}$ Nykänen ja Räbinä ovat todenneet, että ratkaisua tulisi tulkita osaltaan suppeasti. Ratkaisua tulisi soveltaa oikeusohjeena siten konkurssitilanteeseen. ${ }^{\mathbf{4 7}}$ Näin ollen näyttäytyisi, että kyseisen ratkaisun myötä i) yhtiön osakkeenomistajan myöntämä ii) osakeyhtiölain 12 luvun mukainen pääomalaina katsotaan iii) konkurssissa tämän osakkeiden hankintamenon lisäykseksi. Kyseisten edellytysten täyttyessä pääomalaina muodostuu yksityishenkilön tuloverotuksessa vähennyskelpoiseksi.

Ratkaisun sitominen yksinomaan konkurssitilanteeseen ei kuitenkaan vaikuta perustellulta edellä kuvatun arvonmenetysten lopullisuutta koskevan ratkaisukäytännön valossa. Ratkaisussa KHO 2016:49 todettiin nimenomaisesti, että pääomalaina katsottiin lisäsijoitukseksi yhtiöön. On tärkeää huomata myös, että ratkaisussa sovelletuissa oikeusohjeissa viitataan nimenomaisesti TVL 50.3 §:n arvonmenetystä koskevaan kohtaan. Ratkaisussa ei kuitenkaan arvioida varsinaisesti pääomalainan arvonmenetystä, vaan kyse on edellä kuvatulla tavalla pääomalainan merkityksestä lisäsijoituksena yhtiöön. Pääomalaina vaikuttaa tällöin arvonsa menettäneen osakkeen hankintamenoon. Osakeyhtiölain 12 luvun mukaista pääomalainaa e joka tapauksessa pidetä TVL 50.3 §:n 2 kohdassa tarkoitettuna arvopaperina. ${ }^{\mathbf{4 8}}$ Viittauksen myötä pääomalainan verotuksellinen luonne lisäsijoituksena ei nähdäkseni ole riippuvainen

45 Laina oli i) viimesijainen yhtiön konkurssissa, ii) lainan tai korkojen takaisinmaksu oli sovittu sallituksi vain silloin, kun vapaan oman pääoman ja kaikkien pääomalainojen määrä maksuhetkellä ylittää viimeksi päättyneeltä tilikaudelta vahvistettavan tai sitä uudempaan tilinpäätökseen sisältyvän taseen mukaisen tappion määrän, ja iii) laina oli vakuudeton. Osakeyhtiölain (624/2006) 12 luvun mukainen pääomalaina täyttää kyseiset ehdot. Täysin selvää ei kuitenkaan ratkaisun nojalla ole, rajataanko vähennysoikeus vain osakeyhtiölain 12 luvun mukaisiin pääomalainoihin, sillä esimerkiksi ratkaisussa mainittu vakuudettomuus on luonteeltaan tiukempi ehto kuin osakeyhtiölain 12:11:n 3 kohta. Ratkaisussa ei myöskään suoraan viitata osakeyhtiölakiin. Aiheesta tarkemmin ks. Murto-Unkila, Minna. Yritysjärjestelytja maksukyvyttömyys Yhtiö-, vero-ja insolvenssioikeudellinen tutkimus. Turku, Turun kauppakorkeakoulu, 2018. (Murto-Unkila 2018), s.162.

46 Nykänen ja Räbinä olivat katsoneet ratkaisua edeltävän oikeustilan ajalta, että pääomalainaa tulisi pääsääntöisesti käsitellä yksityishenkilön verotuksessa kuten muutakin vekasaatavaa, jolloin

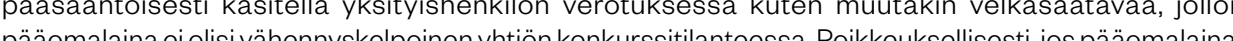

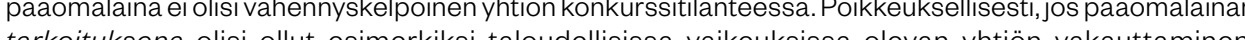
tarkoituksena ollision päăomalaina olisivoitu katsoa osakkeiden hankintamenon lisàykseki. Nykänen -Rảbină 2013, s. 55 Vrt. ratkaisun jälkeiseltä ajalta Nykänen, Pekka - Räbinä, Timo. Ajankohtaiskatsaus luovutusvoiton verotukseen vuodelta 2016, Verotus 2/2017, s. 154-169. (Nykänen - Räbinä 2017), s. 160-161.

47 Nykänen - Räbinä 2017, s. 160

48 Todetaan ratkaisussa KHO 2018:170. 
siitä, onko kyseessä nimenomaisesti konkurssitilanne. ${ }^{49}$ Näin ollen pääomalaina tulee lukea osakkeiden hankintamenon lisäykseksi myös esimerkiksi yrityssaneerauksessa. ${ }^{\mathbf{5 0}}$

Johtuen pääomalainan lisäsijoitusluonteesta ja siitä, ettei kyse voi olla TVL 50.3 §:n 2 kohdassa tarkoitetusta arvopaperista, voidaan katsoa, että pääomalainan vähentäminen esimerkiksi yhtiön konkurssitilanteessa edellyttää, että kyse on nimenomaisesti yhtiön osakkeenomistajan myöntämästä pääomalainasta. ${ }^{51}$ Muun henkilön antama pääomalaina voidaan vähentää tietyissä tilanteissa TVL 50.1 §:n mukaisena luovutustappiona. ${ }^{\mathbf{5 2}}$

\section{JOHTOPÄÄTÖKSET}

Artikkelissa on havaittu, että TVL 50.3 §:n 2 kohtaan liittyy neljä edellytystä. Näistä arvopaperin määrittely on rajattu pois johdannossa kuvatulla tavalla. Arvonmenetys ja lopullisuus on esitetty toisistaan erillisinä edellytyksinä. Konkurssia tai siihen verrattavaa syytä on tarkasteltu perustellusti yhdessä lopullisuuden kanssa, mutta kyseessä ovat erilliset edellytykset.

Oikeuskäytännöstä on havaittavissa ensinnäkin, että tuomioistuimet tarkastelevat osakkeiden lopullista arvonmenetystä kokonaisuutena tilanteissa, joissa osakkeiden arvonmenetys on hyväksytty vähennyskelpoiseksi. Sen sijaan tilanteissa, joissa vähennyskelpoisuus on evätty, perustelut ovat kohdistuneet pääasiassa yksittäiseen edellytykseen. Näin ollen voidaan perustellusti esittää, että säännöksen soveltaminen edellyttää tosiasiassa kaikkien edellytysten

49 TVL 50.3 \&:n 2 kohdassa mainitaan konkurssin ohella myös muu siihen rinnastettava syy.

50 Ks. myös Murto-Unkila 2018, s.161. Verohallinnon ohjeessa asiaan ei oteta täysin selkeästi kantaa. Yhtäältä ohjeessa todetaan, että pääomalainaa pidetään "erityisesti lainan luovutus- ja menetystilanteissa osakkeenomistajan yhtiöön tekemänä lisäsijoituksena riippumatta lainan käyttötarkoituksesta yhtiössä" ja toisaalta "[k]orkeimman hallinto-oikeuden päätöksen (KHO 2016:49) perusteella osakkeenomistajan yhtiölle antamia pääomalainoja voidaan kuitenkin pitää konkurssitilanteessa osakkeen hankintamenoon luettavana lisäsijoituksena". Verohallinnon ohje: Pääomalainojen ja muiden yhtiölle annettujen lainojen luovutukset ja menetykset tuloverotuksessa, 10.10.2019, dnro VH/1746/00.01.00/2019 luku $3.1 \mathrm{ja}$ 3.3. Sana erityisesti viittaa kuitenkin siihen, että pääomalainan lisäsijoitusluonne on käsitetty myös ohjeessa laajaksi.

51 Muulla pääomalainan myöntäjällä kuin osakkeenomistajalla, ei luonnollisesti ole osakkeita, joiden hankintamenoon pääomalaina voitaisiin lisätä. Nykänen, Pekka. Kaksi velkasaatavan luovutuksen verokohtelua koskevaa ratkaisua - KHO 2018:170 ja KHO 14.12.2018 T 5890, Edilex 2019. (Nykänen 2019), s. 2 .

52 KHO 2018:170, jossa A:n B Oy:lle antama laina oli konvertoitu pääomalainaksi. A oli myynyt omistamansa B Oy:n osakkeet sekä pääomalainan saman konsernin C Oy:lle. Esitetyn selvityksen mukaan A oli saanut pääomalainasta vastikkeena niiden nimellisarvoa alhaisemman käyvän arvon. KHO:n ratkaisun myötä A:lle syntyi verotuksessa vähennyskelpoinen luovutustappio. Ks. myös KHO 14.12.2018 taltio 5890, jossa on vahvistettu konvertoidun pääomalainan katsominen osaksi osakkeen hankintamenoa, kun osake on luovutettu. Tässä valossa ratkaisussa KHO 2016:49 omaksutun pääomalainan lisäsijoitusluonteen suppea tulkitseminen ei ole taysin perusteltua. täyttymistä, jolloin kyse on neljästä kumulatiivisesta edellytyksestä. Tämän seurauksena kaikilla edellytyksillä olisi myös itsenäistä merkitystä.

Arvonmenetyksen käsitteen merkitystä TVL 50.3 §:n 2 kohdan soveltumisen kannalta voidaan pitää kuitenkin rajallisena, sillä käsitettä ei ole juurikaan tarkasteltu itsenäisesti oikeuskäytännössä. Arvonmenetyksen merkitys korostuu tarkastellessa KHO:n tapauksia, joissa osakkeiden lopullinen arvonmenetys on hyväksytty vähennyskelpoiseksi. Ratkaisuissa KHO 2011:55 ja KHO 25.10.2016 taltio 4511 osakkeiden lopullinen arvonmenetys hyväksyttiin vähennyskelpoiseksi, vaikka insolvenssimenettely ei ollut vielä päättynyt. Oleellisia ratkaisuissa olivat verovelvollisten esittämät taloudelliset selvitykset yhtiön tilasta ja toiminnasta. Niinpä arvonmenetys sitoo säännöksen soveltumisen taloudellisiin realiteetteihin, mikä on havaittavissa tästä KHO:n tuoreemmasta oikeuskäytännöstä. ${ }^{\mathbf{5 3}}$ Tästä oikeuskäytännön ja tulkintalinjan suunnanmuutoksesta huolimatta viranomaiskäytäntö näyttäytyy vanhaan tulkintakäytäntöön jääneenä. Talouteen pohjautuvassa tulkintatavassa oleellista on osakkeiden lopullisen arvonmenetyksen todennettavuus objektiivisin perustein, millä on puolestaan liitäntä näyttökysymyksiin. Tällöin tulisi kuitenkin erottaa arvonmenetyksen ja sen lopullisuuden aineellisoikeudelliset kysymykset prosessioikeudellisista kysymyksistä.

Arvonmenetyksen lopullisuuden problematiikka liittyy kysymykseen verotuksen jaksottamisesta. Jaksottamisongelman merkitys korostuu esimerkiksi yrityksen konkurssitilanteen pitkittyessä vuosien pituiseksi, jolloin verovelvollinen voi vuosikausia omistaa joko käytännössä arvottomat tai mitättömän arvoiset osakkeet saamatta vähentää niiden hankintamenoa tai saamatta niistä lainkaan tuottoa. Verotus- ja oikeuskäytännössä on jo aiemmin ollut selvää, että osakkeiden lopullinen arvonmenetys tulee kyseeseen viimeistään silloin, kun realisointimenettely päättyy, osakkeenomistajille ei tule menettelyssä jako-osuutta ja yritys purkautuu. Oikeana verovuotena on ollut tällöin realisointimenettelyn päättymisvuosi. Sen sijaan KHO:n tuoreempien ratkaisujen nojalla on todettu, että osakkeiden arvonmenetys voidaan vähentää jo realisointimenettelyn alkamisvuonna, mikäli arvonmenetys on muutoin objektiivisesti todennettavissa. Verohallinto on käytännössään edellyttänyt, että konkurssissa arvonmenetyksen vähennyskelpoisuuden edellytyksenä on tällaisissa tilanteissa pesänhoitajan ilmoitus, jolloin arvonmenetys voidaan vähentää vasta ilmoitusvuonna. ${ }^{\mathbf{5 4}}$ Nimenomaista vaatimusta pesänhoitajan ilmoituksesta osakkeiden lopullisen arvonmenetyksen todentajana eivoida kuitenkaan asettaalain sanamuodon tai oikeuskäytännön nojalla. Lopullisuudessa on pohjimmiltaan kysymys näyttöseikoista ${ }^{\mathbf{5 5}}$ ja

53 Vastaavanlaisia näkemyksiä on esitetty myös vanhemmassa oikeuskirjallisuudessa. Ks. Kukkonen 1994, s.232 ja Andersson, Edward - Linnakangas, Esko. Tuloverotus ja varallisuusverotus. Helsinki, Kauppakaari 2002 (Andersson - Linnakangas 2002), s. 258

54 Ks. Verohallinnon ohje: Ahtium Oyj:n osakkeiden sekä joukkovelkakirjalainojen arvonmenetys tuloverolain mukaisessa verotuksessa, 11.12.2018, dnro VH/2514/00.01.00/2018, kohta 2.

55 Arg. KHO 2011:55 ja KHO 25.10.2016 taltio 4511. 
Lopullisuuden tarkastelu on kohdistunut pääsääntöisesti asian prosessuaalisiin aspekteihin, sillä säännöksen sanamuodosta ja oikeuskäytännöstä on havaittavissa, että osakkeen arvonmenetyksen lopullisuuden todentajana ovat erilaiset realisointimenettelyt. Lopullisuus näyttäytyy puolestaan oikeuskäytännössä näiden realisointimenettelyiden vahvistajana. Tällä tarkoitan sitä, että arvonmenetys voi oikeuskäytännön nojalla olla säännöksessä tarkoitetulla tavalla lopullinen, vaikka realisointimenettely olisikin kesken. Tällaisissa tilanteissa merkitystä onkin ollut asian taloudellisilla seikoilla ja siitä esitetyllä näytöllä. Kysymys on näin loppujen lopuksi sekä taloudellisten että menettelyllisten seikkojen yhteensovittamisesta. ${ }^{\mathbf{5 7}}$

Osaltaan arvonmenetyksen suppea merkitys oikeuskäytännössä on johtunut siitä, että käytännössä varsinkin konkurssitilanteessa yrityksen ja siten myös osakkeen arvottomuuden todentaminen on usein hyvinkin itsestään selvää. Oikeuskäytännön suunnanmuutoksen myötä ja taloudellisten kriteerien vahvistuessa vero-oikeudessa arvonmenetyksen itsenäiselle määrittelylle voi tulla kuitenkin huomattavasti laajempaa tarvetta. Tämän suunnanmuutoksen ansiosta viranomaistoimintaan kohdistunee painetta muuttaa käytäntöjä.

Jaksottamisen ohella tärkeää oikeuskäytännössä on myös ollut arvonmenetyksen suuruuden määrittely. Lähtökohtana tällöin on yksinkertaisesti ollut osakkeiden hankintameno. Noteeraamattomien yhtiöiden osalta tärkeää on käytännössä myös lisäsijoitusten sisällyttäminen yrityksen hankintamenoon. Oikeuskäytännön nojalla onkin selvää, että pääomalainat muodostuvat vähennyskelpoisiksi osakkeiden lopullisen arvonmenetyksen kautta.

Osakkeiden lopullinen arvonmenetyksen konkreettisuuden vero-oikeudellisena ilmiönä osoittaa esimerkiksi johdannossa mainittu Ahtium Oyj. Toisaalta ilmiössä on kyse luonnollisesti myös pienten ja keskisuurten yritysten kohtaamista taloudellisista haasteista. Kyse on siten yksittäisiä ihmisiä koskettavasta tärkeästä verotuksellisesta problematiikasta. Artikkelissa mainitun kehityskulun nojalla näyttääkin selvältä, että osakkeiden lopullisen arvonmenetyksen merkitys vero-oikeudessa jatkaa kasvuaan.

56 Verohallinnon ohjeessa esitetään edellytykseksi, että konkurssipesänhoitaja antaa ilmoituksen, että jako-osuutta ei kerry, tai että konkurssipesän lopputilitys tehdään. Verohallinnon ohje: Arvopaperien luovutusten verotus, 4.10.2019, dnro VH/2358/00.01.00/2019, luku 23.2. Ks. myös aiempi Verohallinnon ohje: Omaisuuden luovutusvoitot ja -tappiot luonnollisen henkilön tuloverotuksessa, 2712 2016, dnro A192/200/2016, luku 13 2. "Näisä tilanteissa osoitukena siitä, että jako-osutta 27.12.2016, dnro A192/200/2016, luku 13.2: "Naissa tilanteissa osoituksena sittä, etta jako-osuutta ei muodostu, on

esitettävä konkurssipesän selvitysmiehen antama todistus".
Ks. Räbinä - Myllymäki - Myrsky 2019, s. 344: "Kun määritetään arvonmenetyksen lopullisuuden ajankohtaa, huomioon tulee ottaa sekä taloudelliset että muodolliset seikat." Vrt. Verohallinnon ohje: Omaisuuden luovutusvoitot ja -tappiot luonnollisen henkilön tuloverotuksessa, 31.10.2019, dnro VH/330/O0.01.00/2019, luku 13.2.1 Ohjeessa ratkaisussa KHO 2011:55 omaksuttua linjaa pidetään nimenomaisesti poikkeuksena pääsääntöön. 